\title{
Innovative outreach increases adoption of sustainable winegrowing practices in Lodi region
}

\author{
by Cliff Ohmart
}

The widespread adoption of sustainable winegrowing practices depends not only on rigorous science, but also on its effective delivery to growers. The Lodi Winegrape Commission (LWC) created a unique self-assessment workbook and implementation program for increasing the adoption of sustainable winegrowing practices. This project was based on results from published research projects - many generated by UC scientists - and on-farm demonstration projects carried out by LWC growers and vineyard consultants. Data from two grower surveys shows that the program led to the increased adoption of specific sustainable winegrowing practices in the Lodi region. It has also served as a model for programs in other wine regions, including in California and New York.

ustainable agriculture and the re-
lated but legally codified organic agriculture have been evolving since the 1920s (Francis and Youngberg 1990). Their importance and implementation have increased dramatically in the last 20 years. Organic agriculture focuses on inputs (e.g., pesticides and fertilizers), with growers following specific practices to become certified. Over the last 10 years, sustainable agriculture has received increased attention from academia, in the media and on the farm. Sustainable agriculture, unlike organic, is not codified at a national level and has the flexibility to address important emerging issues for California agriculture such as water use, air quality, energy use, greenhouse-gas production, wildlife habitat and human resources (Ohmart 2004b).

The California wine industry, relative to other U.S. agriculture sectors,

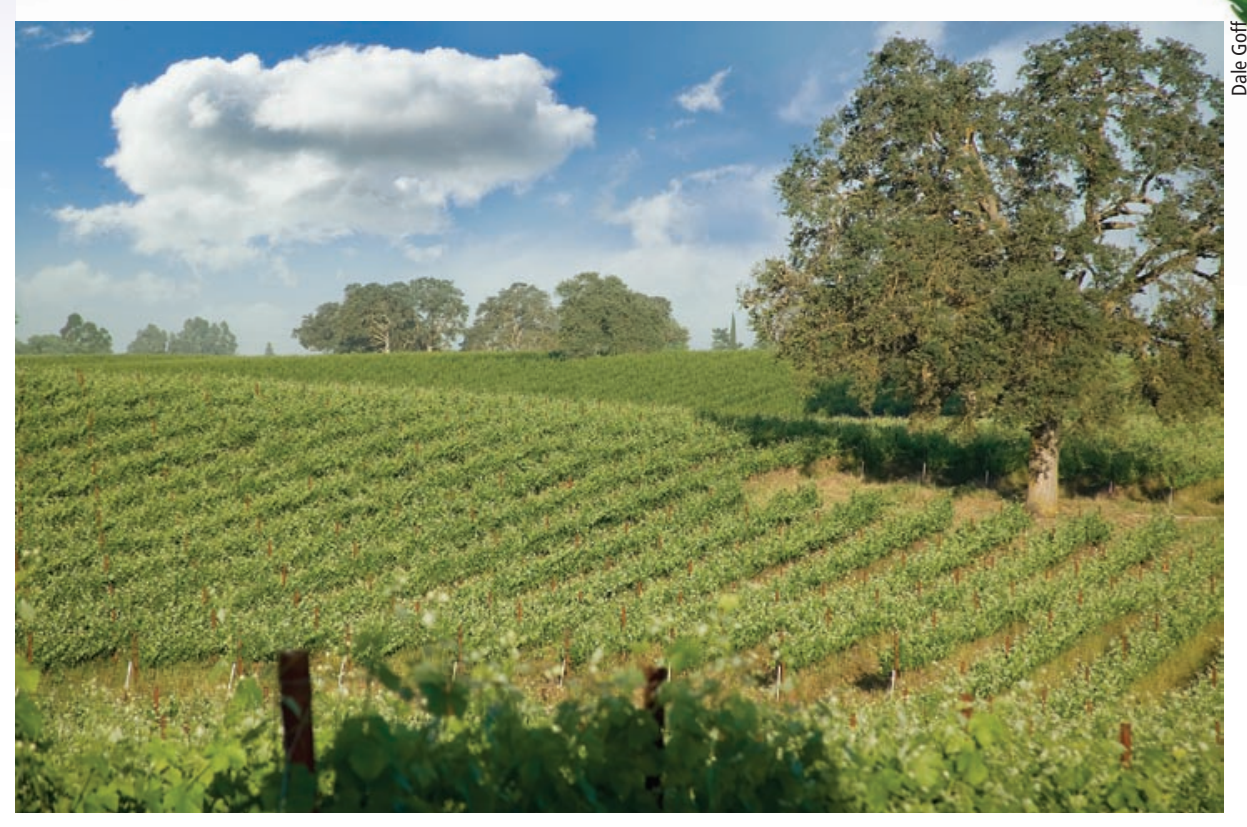

Growers in the Lodi region have embraced sustainable winegrowing practices since the early 1990 s.

has invested a significant amount of effort in encouraging the adoption of sustainable practices in vineyards and wineries (Dlott et al. 2002; Ohmart and Matthiasson 2000; Ohmart et al. 2008; Ackerman et al. 1996) (see page 133). The growers in Lodi have been leaders in this endeavor.

The Lodi Winegrape Commission (LWC) was formed in 1991 by a grower vote. The commission's boundaries are those of California crush district no. 11, in northern San Joaquin County and southern Sacramento County. There are approximately 100,000 acres of winegrape vineyards in this crush district, producing about $20 \%$ of California's total wine-grape crush. Part of LWC's original mission was to develop an areawide sustainable winegrowing program. To accomplish this, LWC formed an Integrated Pest Management (IPM) Program in 1992, consisting of regular grower meetings, field days, a newsletter and a Web site.

In 1995, with help from a Biologically Integrated Farming Systems grant from the UC Sustainable Agriculture Research and Education Program, LWC established on-farm demonstration vineyards where a range of sustainable winegrowing practices were implemented and the results tracked. In 2000, LWC published the Lodi Winegrower's Workbook: A Self-Assessment of Integrated Farming Practices (Ohmart and Matthiasson 2000), and in 2005 launched California's first third-partycertified sustainable winegrowing program, the Lodi Rules for Sustainable Winegrowing (Ohmart 2008; Ohmart et al. 2006).

Growers interested in practicing sustainable winegrowing face three main challenges: defining it, implementing it in the vineyard, and measuring the impacts of implementation (Ohmart 2004a). Once defined, growers must translate sustainable viticulture into day-to-day farming practices. Ideally, practices are based on research results from studies such as those in this issue of California Agriculture. Finally, growers must be able to measure the resulting impacts on farming operations, including on wine grapes and wine quality, farming costs, ecosystem quality and human resources.

The aim of the Lodi Winegrower's Workbook was to increase sustainable winegrowing practices by Lodi growers, and establish benchmarks of adoption to track change over time. The workbook and implementation program 


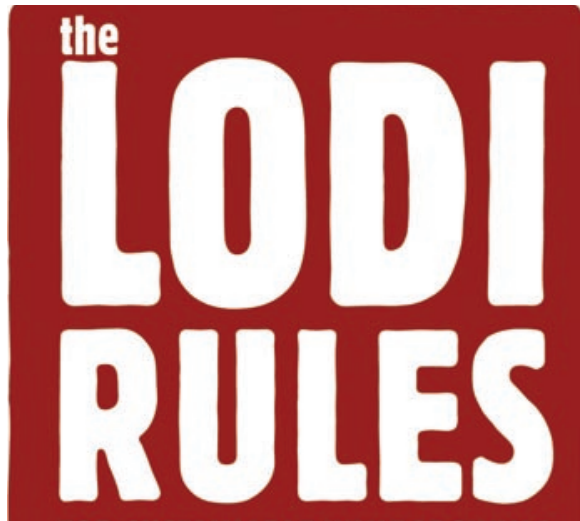

FOR SUSTAINABLE WINEGROWING

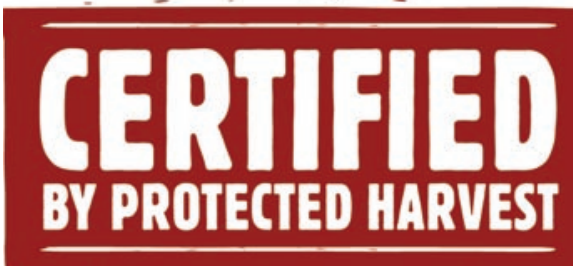

In 2005, the Lodi Winegrape Commission launched California's first third-party certification program for sustainable winegrowing.

were the first of their kind to apply the Environmental Management Systems model (Martin 1998) to wine grapes. They have affected grower attitudes about IPM and increased the adoption of farming practices (Dlott and Dlott 2005). Moreover, the workbook has influenced wine industries in California, Washington state, New York and parts of Australia (Bernard et al. 2007; Dlott et al. 2002; Wise et al. 2007). In 2008, LWC published the Lodi Winegrower's Workbook (2nd ed.) (Ohmart et al. 2008), greatly expanding the content of the first edition.

\section{Defining sustainable winegrowing}

There is no universally accepted definition of sustainable agriculture, and the paradigm continues to evolve. In 2001, the California Association of Winegrape Growers (CAWG) and the Wine Institute formed a joint committee to develop a sustainable winegrowing program that could be implemented statewide. They crafted the following definition: "Growing and winemaking practices that are sensitive to the environment (Environmentally Sound), responsible to the needs and interests of society-at-large (Socially Equitable), and economically feasible to implement and maintain (Economically Feasible)" (Dlott et al. 2002). This definition is often referred to as the three "E's" of sustainability. These 3 E's are common themes reflected in other proposed definitions of sustainable agriculture (ASA 1989; Francis and Youngberg 1990). This simple but comprehensive definition has been widely adopted within the California wine industry, including by Lodi growers.

\section{Implementing sustainable practices}

This definition must be translated into farming practices used to grow wine grapes. In 1998, Lodi growers needed a tool to help them increase the adoption of sustainable winegrowing practices and track the level of adoption over time. An industrywide search identified two promising models. First, the Positive Point System (PPS), developed by the Central Coast Vineyard Team (CCVT), allows winegrape growers to assess the level of sustainability in their vineyards (Ackerman et al. 1998). The second was Farm*A*Syst self-assessment workbooks.

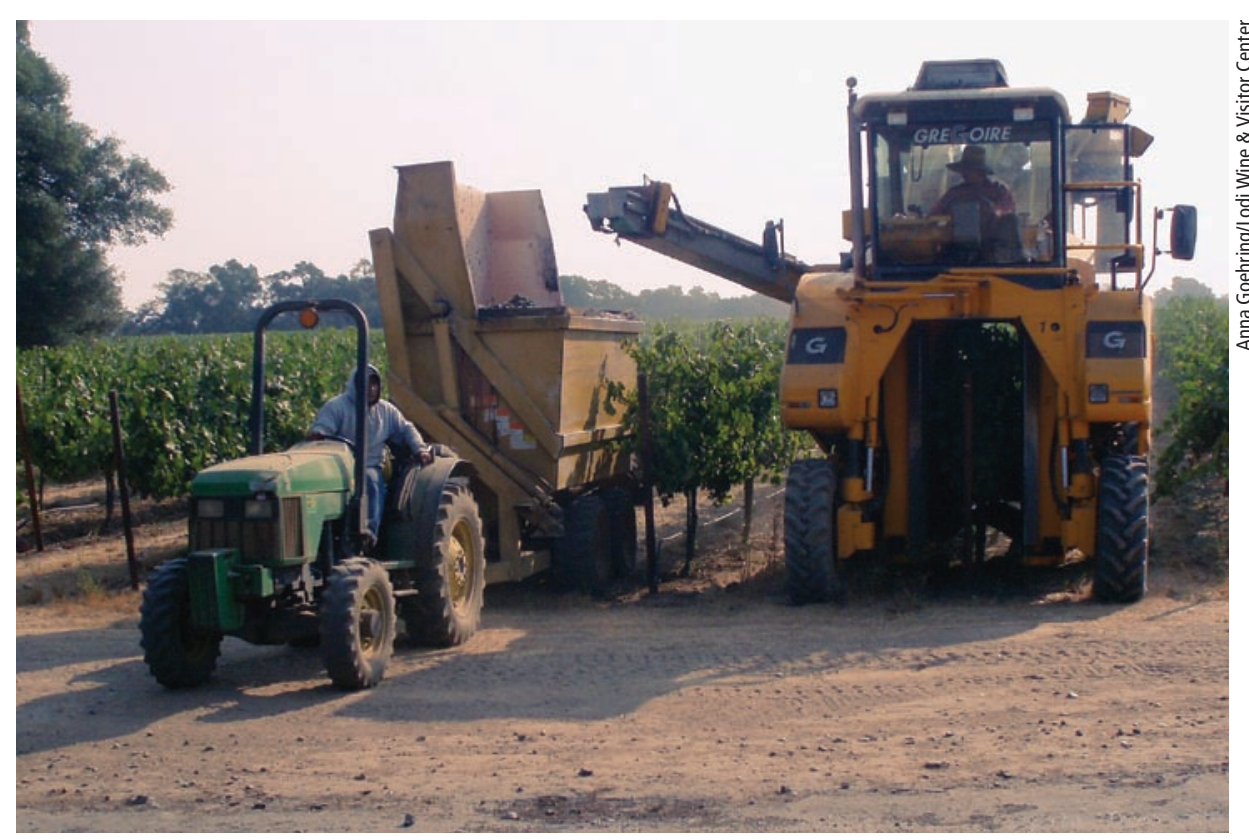

Lange Twins Winery, based in Acampo, credits the Lodi commission as "a catalyst in shaping our philosophy. We have developed our sustainable techniques through their guidelines."
Farm*A*Syst, established in 1991, is a partnership between government agencies and businesses to prevent pollution on farms, ranches and in homes using confidential environmental assessments. It is a national program supported by the U.S. Cooperative State Research, Education, and Extension Service, Natural Resources Conservation Service, and U.S. Environmental Protection Agency (EPA). FarmA*Syst's approach is based on the Environmental Management Systems (EMS) model as a standard process to develop goals, implement them, measure success and make further improvements (Martin 1998; WCED 1987).

Based on this model, producers in the United States, Canada and Australia developed self-assessment workbooks for dairy, cotton and other crops. The Farm ${ }^{*} A^{*}$ Syst workbooks help growers to identify farming practices that are beneficial from an environmental perspective and those that are having negative impacts; create action plans and timetables to address practices causing environmental concern; and obtain information to help develop and carry out action plans.

The Farm*A*Syst workbook model had two attributes that other selfassessments, such as the Positive Point 


\begin{tabular}{|c|c|c|c|c|c|c|}
\hline Viticulture & Soil management & Water management & Pest management & Habitat & Human resources & Wine quality \\
\hline Canopy management & $\begin{array}{l}\text { Plant tissue, } \\
\text { soil sampling and } \\
\text { analyses }\end{array}$ & $\begin{array}{l}\text { Water-quality } \\
\text { monitoring }\end{array}$ & Pest monitoring & $\begin{array}{l}\text { Nest boxes for birds } \\
\text { of prey }\end{array}$ & $\begin{array}{l}\text { Grower continuing } \\
\text { education }\end{array}$ & $\begin{array}{l}\text { Knowledge of wine } \\
\text { quality }\end{array}$ \\
\hline Vine balance & $\begin{array}{l}\text { Nitrogen } \\
\text { management }\end{array}$ & $\begin{array}{l}\text { Offsite water } \\
\text { movement }\end{array}$ & $\begin{array}{l}\text { Insect and mite } \\
\text { management }\end{array}$ & $\begin{array}{l}\text { Planting of insectary } \\
\text { plants }\end{array}$ & $\begin{array}{l}\text { Participation } \\
\text { in professional } \\
\text { organizations }\end{array}$ & $\begin{array}{l}\text { Knowledge of wine } \\
\text { industry }\end{array}$ \\
\hline $\begin{array}{l}\text { Monitoring canopy } \\
\text { microclimate }\end{array}$ & $\begin{array}{l}\text { Nutrient } \\
\text { management besides } \\
\text { nitrogen }\end{array}$ & $\begin{array}{l}\text { Irrigation system } \\
\text { selection }\end{array}$ & $\begin{array}{l}\text { Use of broad- } \\
\text { spectrum pesticides }\end{array}$ & $\begin{array}{l}\text { Use of pesticides in } \\
\text { relation to wildlife }\end{array}$ & $\begin{array}{l}\text { Regulation } \\
\text { compliance }\end{array}$ & $\begin{array}{l}\text { Monitoring fruit } \\
\text { maturity }\end{array}$ \\
\hline Environmental survey & Water infiltration & $\begin{array}{l}\text { Irrigation system } \\
\text { performance }\end{array}$ & $\begin{array}{l}\text { Use of reduced-risk } \\
\text { pesticides }\end{array}$ & $\begin{array}{l}\text { Wind erosion } \\
\text { and offsite water } \\
\text { movement reduction }\end{array}$ & $\begin{array}{l}\text { Employee training } \\
\text { and education }\end{array}$ & $\begin{array}{l}\text { Monitoring juice } \\
\text { chemistry }\end{array}$ \\
\hline Rootstock selection & $\mathrm{pH}$ management & $\begin{array}{l}\text { Irrigation system } \\
\text { maintenance }\end{array}$ & Disease management & $\begin{array}{l}\text { Establishing wildlife } \\
\text { corridors }\end{array}$ & $\begin{array}{l}\text { Team-building } \\
\text { among employees }\end{array}$ & $\begin{array}{l}\text { Tasting wine with } \\
\text { winemaker }\end{array}$ \\
\hline Clone selection & $\begin{array}{l}\text { Organic matter } \\
\text { management }\end{array}$ & $\begin{array}{l}\text { Water-use } \\
\text { monitoring }\end{array}$ & Weed management & Farmscaping & $\begin{array}{l}\text { Safety reward } \\
\text { programs }\end{array}$ & $\begin{array}{l}\text { Viticultural } \\
\text { improvements based } \\
\text { in wine quality }\end{array}$ \\
\hline Trellis selection & Tillage & Water budgeting & $\begin{array}{l}\text { Vertebrate pest } \\
\text { management }\end{array}$ & $\begin{array}{l}\text { Vernal pool } \\
\text { management }\end{array}$ & Employee meetings & $\begin{array}{l}\text { Communication with } \\
\text { winery }\end{array}$ \\
\hline Habitat conservation & Erosion & Deficit irrigation & $\begin{array}{l}\text { Spray-drift } \\
\text { management }\end{array}$ & $\begin{array}{l}\text { Riparian area } \\
\text { management }\end{array}$ & $\begin{array}{l}\text { Employee } \\
\text { professional } \\
\text { development }\end{array}$ & $\begin{array}{l}\text { Tasting grapes in the } \\
\text { vineyard with winery } \\
\text { rep }\end{array}$ \\
\hline
\end{tabular}

System, lacked. One was that farming issues in the workbook are addressed using a four-category system rather than simple "yes/no" answers. The other encourages growers to develop action plans to address the concerns discovered during the self-assessment. After problems are identified, the action plan puts a grower on the path of continual improvement.

The Lodi growers chose to adopt the EMS/Farm*A*Syst model, then established goals and principles for the program through facilitated discussion (Ohmart and Matthiasson 2000). By doing so they took ownership of the program, helping ensure wide adoption by their peers. They felt growers would be much more likely to use a workbook developed by other stakeholders in their region than one developed by an outside group.

Previous Farm* $A^{*}$ Syst workbooks focused on environmental concerns and placed educational information in appendices. Lodi growers chose to not only address important environmental issues but also focus on farming practices that affect wine-grape quality. Furthermore, they chose to integrate throughout the workbook educational information about the most important topics to aid growers in developing their action plans.

\section{Writing the Lodi workbook}

No textbooks are devoted to sustainable winegrowing, and the most recent general viticulture text is almost 35 years old (Winkler et. al. 1974). However, advances have continued since then, as shown in publications by UC researchers and other institutions on specific aspects of wine-grape growing, such as Grape Pest Management (Flaherty et al. 1992), Cover Cropping in Vineyards (Ingels et al. 1998) and Deficit Irrigation of Quality Winegrapes Using Micro-irrigation Techniques (Prichard et al. 2004) (see also Adler 2002; Broome et al. 2000; Petersen et al. 1978; Schwankl et al. 1993; Smart and Robinson 1992). There is also a substantial pool of knowledge about sustainable winegrowing in the collective experience of growers, farm advisors, research scientists and others. To take advantage of this published and collective knowledge, a 17-member committee was recruited to develop the workbook, which included Lodi wine-grape growers, vineyard consultants, UC researchers and farm advisors, wildlife biologists, and representatives of the U.S. EPA, Natural Resources Conservation Service and Farm ${ }^{*} A^{*}$ Syst.

Following the Farm ${ }^{*} A^{*}$ Syst model, the next step was to identify all issues that related to growing wine grapes in the Lodi region, not just those pertaining to inputs such as fertilizers and pesticides. The committee identified 105 issues, which were categorized into seven chapters: viticulture, soil management, water management, pest management, habitat, human resources and wine quality (Ohmart and Matthiasson 2000) (table 1).

The committee then created worksheets for each issue listing farming practices available to Lodi wine-grape growers to address them. Each practice influences one or more of the three E's of sustainability, either positively or negatively. In some cases a practice might be positive for one and negative for one or both of the others. For example, a pesticide may be effective and inexpensive but also highly toxic to workers and wildlife.

After the practices were listed for each issue they were arranged into four categories on each worksheet, with category 1 for least-sustainable practices, getting progressively more sustainable in categories 2 and 3, and ending with the most-sustainable practices in category 4 (table 2). Decisions on what practices to list and the level of sustainability for each were based on research results, as well as on the knowledge and experience of the committee members. 
TABLE 2. Worksheet for issue no. 11 in soil management chapter of Lodi Winegrower's Workbook

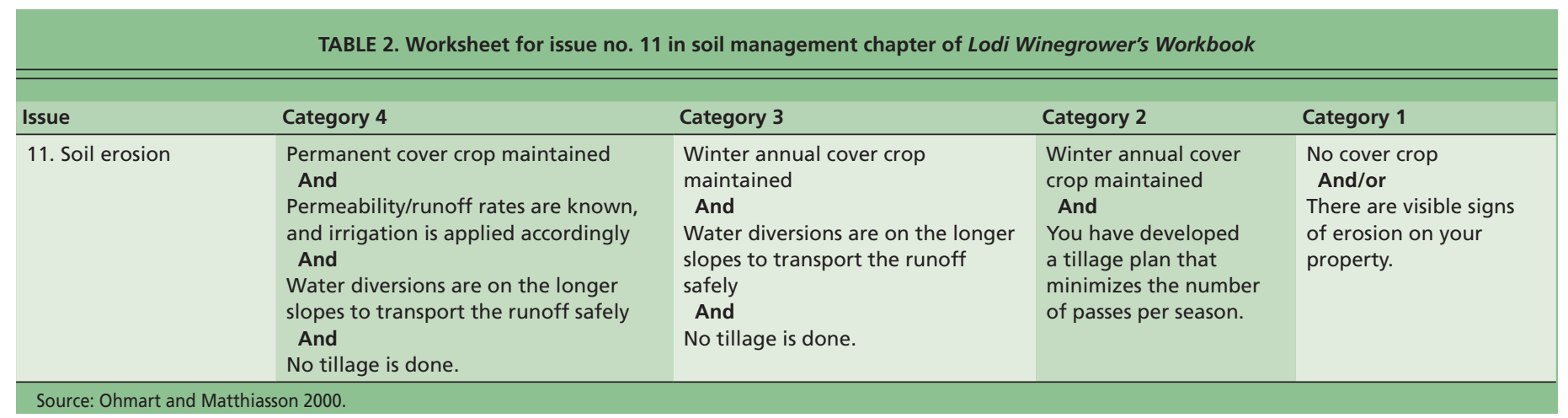

The final step in writing the workbook was to add educational information about specific issues and practices. The workbook was not intended to be a textbook on wine-grape growing, but the committee believed that certain scientific information should be included, either as a stimulus for growers to find out more or as practical guide to create and carry out action plans.

\section{Implementing the workbook program}

It takes growers about 3 hours to complete the 105 worksheets. There is a summary evaluation sheet for each chapter on which growers record their level of sustainability based on whether their practices best match category 1,2 , 3 or 4 . In the subsequent review of the summary evaluation sheets, issues are identified where improvements can be made and an action plan is created. The most serious concerns are identified by issue scores of 1 or 2 .

We decided the best way to get busy growers to look at the workbook in depth was to assemble small groups and go through it with them. Key growers in the district were asked to invite 5 to 10 of their neighbors over to fill out the workbooks together. During the first 18 months after the first workbook was published in 2000, 36 workshops were attended by 265 growers managing about 60,000 acres of Lodi vineyards (about two-thirds). Growers took their host role seriously, in some cases trying to out-do each other by serving snacks, wine and coffee; one workshop was held in a pizza parlor.

\section{Measuring adoption}

Measuring the level of adoption for sustainable farming practices is difficult, because sustainable agriculture addresses all aspects of farming and encompasses a huge range of practices that fall all along the continuum of sustainability. The four-category worksheet of the Farm* ${ }^{*}$ Syst workbook model is excellent for dealing with this complexity. The evaluation scores from the workbook can be used to assess the level of adoption for an individual vineyard and grower as well as for a group of growers in a region or larger geographic area.

An individual grower can use the evaluation sheets as a summary of their assessment. If they carry out one or more action plans, their vineyard practices can be reassessed after one or two seasons to track improvements over time. Likewise, a group of growers in a region can pool their evaluations into a common database. For example, LWC created a Microsoft Access database to capture and summarize self-assessments from growers willing to anonymously share their vineyard evaluations.

Assessment data from a group of vineyards and/or growers can be summarized in several ways. One is to calculate an average "score" for each workbook issue. For example, if the average for issue 11 shown on table 2 is a 3, then the average vineyard in the database maintains a winter cover crop, has water diversions on any long slopes and no tillage is done. We have used these data summaries to determine which farming issues require more attention in LWC grower outreach meetings. Likewise, growers can see how they compare to the regional average.

\section{Assessing impacts on practices}

We attempted to measure the impact of LWC's outreach program on farming

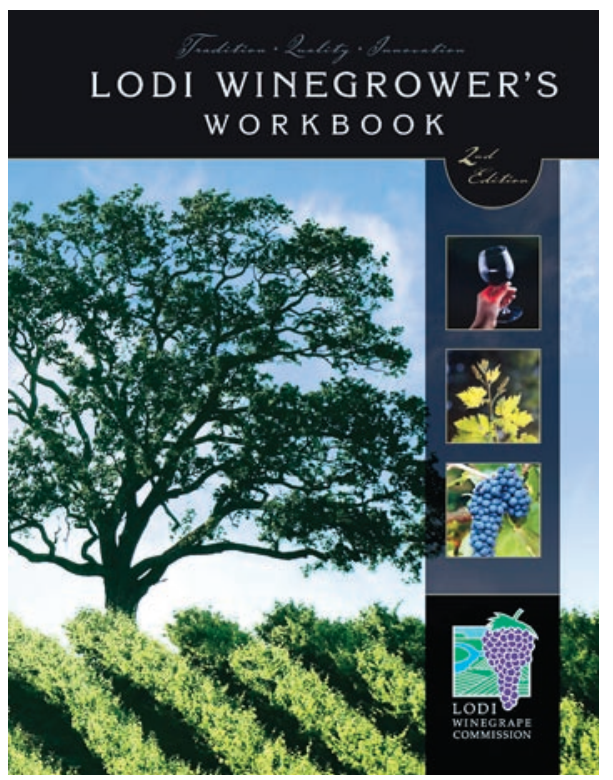

Growers managing more than two-thirds of vineyard acres in the Lodi region have assessed their practices using the Lodi Winegrower's Workbook.

practices by conducting grower surveys of more than 700 members of the LWC in 1998 and 2003. The goals were to: assess the quality of LWC's outreach program, including the workbook; identify the sources of educational information used by growers and how important they are; measure the impact of LWC's outreach program on specific farming practices; assess perceptions of IPM; and gather demographic information.

Since LWC's outreach program has focused on IPM - from its inception in 1992 until the publication of the Lodi Winegrower's Workbook in 2000 - the 1998 survey questions focused on IPM. The 2003 survey also focused on IPM, including many of the same questions, so that the results would be comparable. As a result, data presented here is primarily related to IPM. 


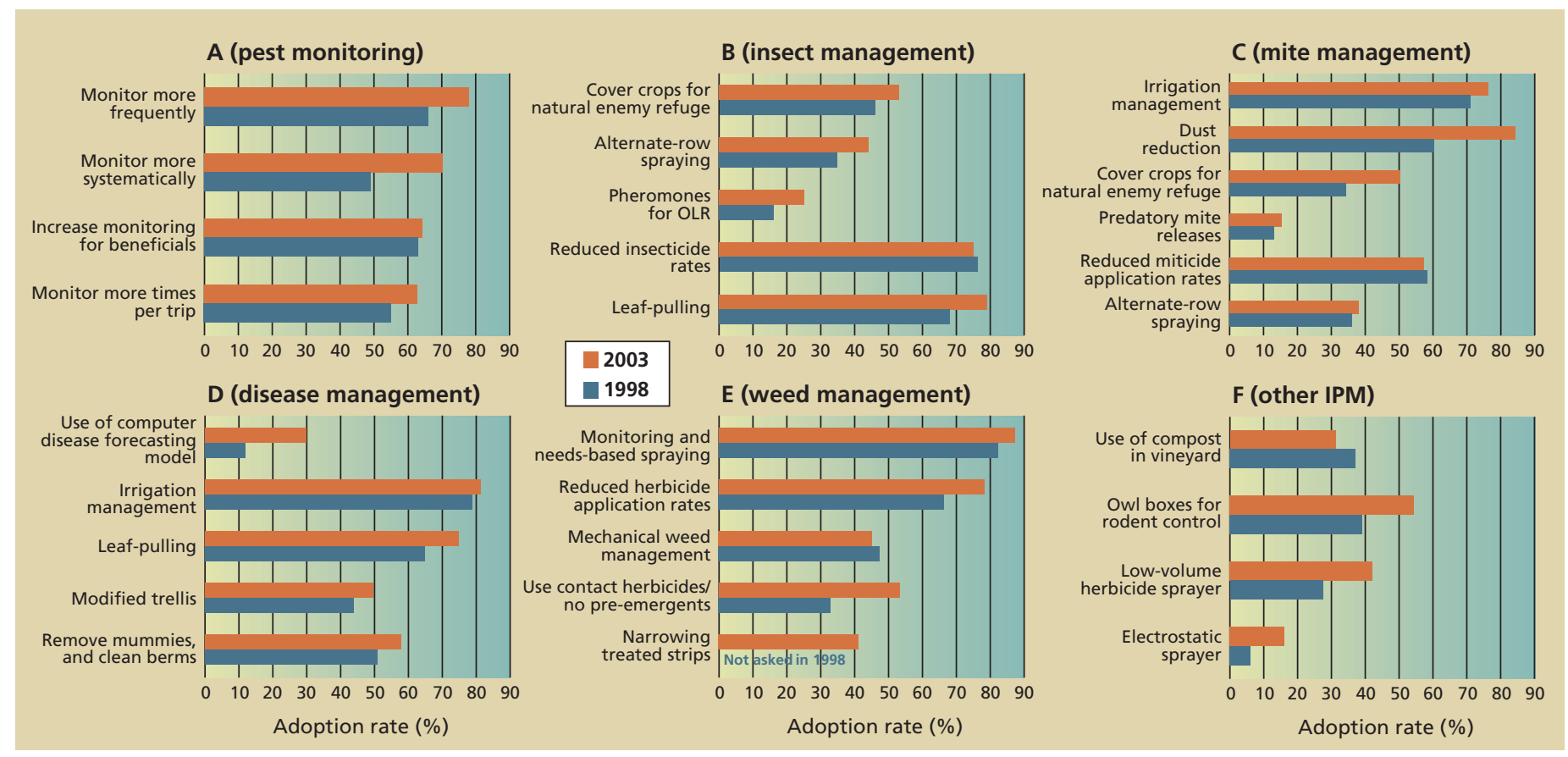

The 1998 and 2003 grower surveys where designed and carried out by Dlott and Dlott (2005), based on the mail and telephone survey Total Design Method (Salant and Dillman 1994; Dillman 2000), with guidance from the LWC Research Committee. Two weeks after the first mailing, a reminder/ thank-you postcard was mailed to all growers, managers and pest control advisors (PCAs). Replacement questionnaires were mailed to those who had not returned their questionnaires at 4 , 6 and 8 weeks after the initial mailing. The response rate in both years exceeded $44 \%$, making the results statistically accurate to plus or minus 5\%.

Since its inception in 1992, LWC's outreach program emphasized the importance of monitoring to manage vineyard pests, so growers were asked how their monitoring practices had changed (fig. 1A). By 1998, a large portion of growers had changed their monitoring practices, and there was a modest-to-large improvement in all categories between 1998 and 2003. For example, in 2003, 78\% reported monitoring more frequently, up $12 \%$ from 1998; and 70\% reported monitoring more systematically, up $21 \%$. Monitoring for beneficial insects did not change appreciably, remaining at just under two-thirds, but $63 \%$ of respondents reported an increase in the amount of monitoring time per trip, an increase of $8 \%$.

The percentage of growers using IPM to manage insects, mites, diseases and weeds, as well as other IPM practices, showed a modest-to-large increase in adoption in all but 4 of the 20 practices surveyed (figs. 1B-F). The increase in implementation of several practices exceeded 20\% from 1998 to 2003 . We hypothesize that growers increased monitoring more systematically (fig. 1A), most likely because when monitoring, one quickly realizes that systematic monitoring provides data that is comparable from one vineyard to another and from one time to another. Growers increased their adoption of dust-reduction strategies because of an increased appreciation for its role in mite outbreaks, as well as increased air-quality concerns in the Lodi region.

The increased use of computer models for disease forecasting (fig. 1D) is most likely explained by a general increase in the use of computers by growers from 1998 to 2003. Finally, the increase in replacement of pre-emergent herbicides with contact herbicides for under-the-vine weed management (fig. 1E) is likely due to an increase in
Fig. 1. Percentage of growers using specific practices for (A) pest monitoring, (B) insect pest management, (C) mite management, (D) disease management, $(E)$ weed management and (F) other IPM practices for pest management, based on grower survey results from 1998 and 2003. Source: Dlott and Dlott 2005.

grower appreciation of groundwater contamination by certain pre-emergent herbicides such as simazine.

The small increase in rate of adoption for some practices, such as monitoring more frequently (fig. 1A), reduced insecticide rates (fig. 1B), irrigation management for mites and diseases (figs. 1C and D) and reduced herbicide rates (fig. 1E) is likely due to the adoption rate being so high in 1998 that there was not much room for a large increase in 2003.

By 2002, growers managing over twothirds of the vineyard acres in Lodi had assessed their practices using the workbook. Since the workbook program was the major outreach effort carried out by LWC between the two grower surveys, the increases in adoption of farming practices can at least in part be attributed to the workbook program.

\section{Shifting the paradigm}

The paradigm of sustainable winegrowing continues to evolve. Because 
it encompasses all aspects of a farming operation and a wide range of practices, it is useful to think of it as a continuum from "not sustainable" on one end to "very sustainable" on the other. A perfectly sustainable vineyard is not likely, in part because what is considered sustainable today may not be rigorous enough tomorrow. Moreover, growing grapes leaves an environmental footprint and there will always be something that can be done to make that footprint smaller. The world of sustainable agriculture is one where the horizon is always receding; this is a source of frustration for some wine-grape growers because it is human nature to want to arrive at an endpoint rather than at some point along a continuum.

A Farm*A*Syst self-assessment workbook is well suited to dealing with this situation. First, it encompasses the complete range of practices for each farming issue, from less sustainable to most sustainable. Second, for every farming issue, it provides a road map of practices, showing growers exactly what their level of sustainability is and what they can do to improve. Third, it encourages them to create and carry out action plans to make improvements. And finally, it provides an objective measurement to help growers track themselves either individually or as a group. In the future, metrics around sustainable winegrowing will need to move past simply tracking practices and include performance measures, such as the amount of energy expended and gallons of water used per ton of grapes produced, as well as balancing multiple factors along with farm-gate income.

Implementing the workbook program through small workshops around the kitchen table in growers' homes and shop benches was unique and has had numerous positive outcomes. It got growers to open the workbook and discover its value so they would use it. As growers did the self-assessment they would ask the person next to them how they dealt with certain farming issues. Invariably lively discussions ensued, with growers sharing valuable information. Finally, the workbook program gave the Lodi growers a real sense of meeting the challenges of sustainable winegrowing as a community, and led to increased adoption of IPM practices.

C. Ohmart is Sustainable Winegrowing Director, Lodi Winegrape Commission. US EPA Region 9, the CalFed Bay Delta Program and the Great Valley Center provided partial funding for the first edition of the Lodi Winegrower's Workbook; the California State Water Resources Control Board provided partial funding for the second edition.

\section{References}

Ackerman D, Bettiga L, Bianchi M, et al. 1998. Central Coast Vineyard Team Positive Point System. Practical Winery Vineyard 29(1):12-24.

Adler S. 2002. California Vineyards and Wildlife Habitat. Calif Assoc Winegrape Growers. Sacramento, CA. $96 p$

[ASA] American Society of Agronomy. 1989. Decisions reached on sustainable agriculture. Agron News (Jan). p 15

Bernard M, Horne PA, Papacek D. 2007. Guidelines for environmentally sustainable winegrape production in Australia: IPM adoption self-assessment guide for growers. Austral N Zeal Grapegrower Winemaker (March):24-35.

Broome JC, Scott LC, Hoffman B. 2000. Growers' Guide to Environmental Regulations and Vineyard Development. UC Sustainable Agriculture Research Education Program and California Association of Winegrape Growers. Sacramento, CA. $110 \mathrm{p}$.

Christensen LP, Dokoozlian NK, Walker MA, Wolpert JA (eds.). 2003. Wine Grape Varieties in California. UC ANR Pub 3419. $188 p$

Dillman DA. 2000. Mail and Internet Surveys: The Tailored Design Method (2nd ed.). New York: J Wiley. $464 \mathrm{p}$.

Dlott J, Dlott F. 2005. Lodi-Woodbridge Winegrape Commission 2003 and 1998 Grower Questionnaires: 2003 and 1998 Report of Results. www.lodiwine.com/ Grower_Survey_LWC_Final_report.pdf. 53 p.

Dlott J, Ohmart CP, Garn J, et al. (eds.). 2002. The Code of Sustainable Winegrowing Practices Workbook. Wine Institute and Calif. Assoc. Winegrape Growers. 477 p.

Flaherty DL, Christensen DL, Lanini T, et al. 1992. Grape Pest Management. UC ANR Pub 3343. 400 p.

Francis CA, Youngberg G. 1990. Sustainable agriculture - An overview. In: Francis CA, Flora CB, King LD (eds.). Sustainable Agriculture in Temperate Zones. New York: J Wiley. p 1-12.

Ingels CA, Bugg RL, McGourty GT, Christensen LP. 1998. Cover Cropping in Vineyards. UC ANR Pub 3338. $162 \mathrm{p}$.

Martin R. 1998. ISO 14001 Guidance Manual. National Center for Environmental Decision Making Tech.

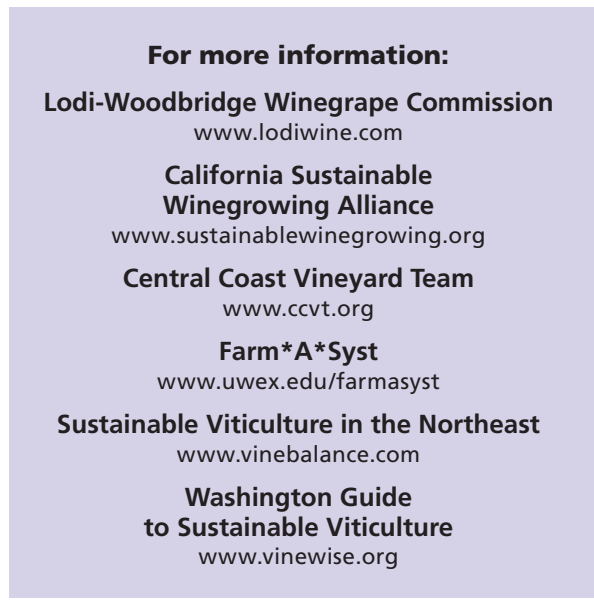

Rep. NCDER/98-06. www.iso14000-iso14001environmental-management.com. 97 p.

Ohmart CP. 2004a. The challenges to implementing sustainable viticulture. Wines Vines 85(10):40-2

Ohmart CP. 2004b. What does sustainability really mean? Wines Vines 85(11):20-3.

Ohmart CP. 2008. Lodi Rules certified wines enter the marketplace. Practical Winery Vineyard 29(5):32-42.

Ohmart CP, Matthiasson S. 2000. Lodi Winegrower's Workbook: A Self-Assessment of Integrated Farming Practices. Lodi-Woodbridge Winegrape Commission. Lodi, CA. 145 p.

Ohmart CP, Storm CP, Benbrook CM. 2006. Lodi Rules certification advances sustainable viticulture. Practical Winery Vineyard 27(6):7-23.

Ohmart CP, Storm CP, Matthiasson S. 2008. Lodi Winegrower's Workbook (2nd Edition). Lodi Winegrape Commission. Lodi, CA. 350 p.

Petersen LP, Kasimatis AN, Jensen FL. 1978. Grapevine and Nutrition Fertilization in the San Joaquin Valley. UC ANR Pub 4087.40 p.

Prichard T, Hanson B, Swankl L, et al. 2004. Deficit Irrigation of Quality Winegrapes Using Micro-irrigation Techniques. UCCE Dept. of Land, Air, Water Res. UC Davis. 89 p.

Salant P, Dillman DA. 1994. How to Conduct Your Own Survey. New York: J Wiley. 232 p.

Schwankl L, Hanson B, Prichard T. 1993. Low-Volume Irrigation. UC Irrigation Program, UC Davis. 116 p.

Smart R, Robinson M. 1992. Sunlight into Wine: A Handbook for Winegrape Canopy Management. Adelaide, Aust.: Winetitles. 88 p.

Winkler AJ, Cook JA, Kliewer WM, Lider LA. 1974 General Viticulture. Berkeley, CA: UC Pr. 710 p.

Wise A, Martinson T, Hawke J, et al. 2007. New York Guide to Sustainable Viticulture Practices: Grower Self-Assessment Workbook. Cornell Univ Cooperative Extension. www.vinebalance.com.

[WCED] World Commission on Environment and Development. 1987. Our Common Future. Oxford Univ Pr. 398 p. 